\title{
Promoting Local Wisdom in Narrative Text: The Role of WebQuest
}

\author{
Johara Indrawati* \\ English Language Education Department \\ Yogyakarta State University \\ Yogyakarta, Indonesia \\ joharaindrawati@gmail.com
}

\author{
Widyastuti Purbani \\ English Language Education Department \\ Yogyakarta State University \\ Yogyakarta, Indonesia \\ purbani@uny.ac.id
}

\begin{abstract}
This study is aimed at promoting local wisdom through narrative text with the use of WebQuest. In the $21^{\text {st }}$ century, students are required to master English in order to face the ASEAN Economic Community. However, students have to remember and maintain local wisdom in their country. English must be mastered by the students but local wisdom must not be forgotten. Therefore, narrative text material will be developed by incorporating local wisdom in Indonesia through WebQuest as a learning tool. There are five stages in this study including need analysis, material development, expert validation, and revision. Students are confronted with situations that require them to learn folktales in their area through WebQuest. There are some benefits of using WebQuest in teaching and learning such as (a) WebQuest help the learners to learn English and understand the local wisdom in their area. (b) WebQuest makes it easy for learners to find information about the culture that is in their area. (c) WebQuest increases the independence of learners in finding information and understanding narrative text. Tenth-grade students at one of the vocational high schools in Yogyakarta participated in this research development. The result indicates that material development through WebQuest is applicable, appropriate, and attractive to use by the students. Thus, promoting local wisdom by using WebQuest can increase learners' knowledge about local wisdom in their country.
\end{abstract}

Keywords-WebQuest, local wisdom, narrative text

\section{INTRODUCTION}

In this digital era, most people work using technology. The International Telecommunication Union (ITU) reports that almost half of the global population uses the internet. This statement is supported by Internet World Stats which informs that internet users in the world in 2019 are 4.536 billion from 7.716 billion population. The increase of technology users every year has made technology the most dominant contributor to society in the 21 st century. It proves that people around the world are starting to need technology to make their work easier.

However, technology is considered as a tool that can improve teaching and learning (Ahmadi, 2018). Teachers began to use technology and the internet as tools and materials for teaching. While students use technology and the internet to find information from teaching provided by teachers. Previous research reports that nowadays students begin to place technology as part of their learning (DfES, 2002). Through technology, students can connect with various sources of information that they have never known so they can use it in learning (Prajogo \& Ahmed, 2006). Technology can also increase access for teachers and students to the latest learning resources so that they can make students became independent learners by searching for information they need on the internet (McKnight, Kathrine \& O'Malley, Kimberly \& Ruzic, Roxanne \& Horsley, Maria \& Franey, John \& Basset, 2016). In addition, students can be motivated and supported to be responsible for their own learning (Littlejohn \& Higgison, 2003). In other words, technology has a major contribution to the teaching and learning process.

However, technology may not be able to solve all problems in education. Technology can influence the gap between cultures (Kurt \& Gok, 2015). When using the internet, students can easily accept and adapt to a variety of different cultures. This affects the fading of local culture because students began to be influenced by the various cultures they received through the use of the internet. Therefore, students need to be introduced to local wisdom in Indonesia so that they do not lose their identity as Indonesian citizens. The function of introducing local wisdom to students is making them have good ethics and morals. Students can also develop culture and knowledge through the introduction of local wisdom. So, technology will have a positive impact if used appropriately and in accordance with the objectives of teaching and learning (Harrison, 1997).

To overcome the lack of local culture, teachers can use narrative text types to promote local culture. The narrative is a piece of text that tells a story to entertain and tell the reader and listener (Anderson \& Anderson, 1997). This statement is also supported by Alcantara (2003) who said that the narrative text is a text that tells a story and aims to entertain. In narrative text, there are characters, settings, and actions (Alcantara, 2003). The characters, settings and the problem are usually raised in the beginning. The problem reaches the highest peak in the middle and at the end is used to solve the problem. In addition, Anderson \& Anderson (2003) explain the text structure of the narrative text that divide into five steps namely orientation, complication, sequence of events, resolution, and coda. In orientation, the narrator tells who is in the story, when it happened, where it happened, and what happened. In complication, the narrator shows the sequence of events that 
appears. Then, in the sequence of events, the narrator shows how the character's reaction to the problems that arise. In resolution, existing problems can be resolved. Finally, the coda, where the moral message is shown in the story. Based on the explanation of the narrative text, the teacher can incorporate local culture into the narrative text, for example using legendary stories from Indonesia to remind students that it has moral values that are useful for their life.

Besides promoting local culture, teaching narrative text to students can improve their reading skills. Puspita (2017) reports that students in Indonesia have difficulties in understanding the texts they read. Whereas Oberholzer (2005) states that it is far more critical for us to understand what we are learning than to learn the mechanical skill to read. Learning would not serve any purpose without comprehension. This means that reading text comprehension is the most important aspect. In addition, Sasmita (2012) reports that the factors that make students difficult to understand reading are vocabulary, grammar knowledge, and reading interest while Atikah (2009) adds that the contributing factors are vocabulary, grammar, and spelling. To overcome that problem, what are the appropriate learning materials and tools that contain local wisdom values and can improve students' reading skills?

Nowadays, developing material through technology and internet is crucial because the development of technology grows rapidly. It can make students switch to use the technology. Therefore, learning tools are needed to help students knowing and remembering the local culture that they have received from a young age. WebQuest is one of the learning tools that can be used to promote local culture because teachers can enter sources of information about subject matter that is linked to local culture. WebQuest is an inquiry-based teaching and learning tool that uses pre-designed internet resources (Dodge, 1995). Webquest can be used by all levels and ages in various subject areas (Ezell, Klein, Hines \& Hall, 2003). In addition, the quality of teaching and learning can be enhanced by the frequent use of WebQuest (Ezell, Klein, Hines \& Hall, 2003). Webquest can provide effectiveness in promoting student engagement, motivation, connecting to authentic context, critical thinking, higher-order thinking, literacy, and integration of information and communication technology (Abbitt \& Ophus, 2008). The study from Seitkazy, Toleubekova, Amanova, Tatshetov, Iskakova, and Demissanova (2016) showed that the use of WebQuest is useful for facilitating knowledge attainment and supporting problembased learning. Then, the study from Zheng, Perez, Williamson, and Flygare (2007) report that the use of WebQuest can increase students' social skills. According to those previous studies, it is known that some studies have not used WebQuest to promote local wisdom so that students' knowledge about local culture increases. Thus, the researchers would like to insert local wisdom to teaching and learning using WebQuest. The reason is to increase the students' knowledge of their local culture.
Moreover, there are several reasons for implementing WebQuest in the class (Marzano, 1992). The first reason, WebQuest makes students become active learners. WebQuest asks students to think at a higher level. Besides reading and remembering, students can also apply, synthesize, analyze, and evaluate. The second reason is that students can find the latest course books and materials on the internet so that students do not rely too much on printed books. The last reason is that WebQuest can be done in groups so that students can share knowledge with group members to get a better understanding of the material and respect the opinions of each member. In addition, implementing WebQuest in the classroom can improve students' critical thinking, facilitate knowledge applications, and develop collaborative skills in learning (Brucklacher \& Gimbart (1999).

WebQuest consists of six stages to introduce activities and processes that students must carry out. Dodge (1997) describes the six parts of WebQuest which consist of (a) introduction, which provides preliminary information for carrying out activities; (b) tasks, which contain interesting assignments or activities that enable students to learn and improve their current knowledge by gathering information through WebQuest; (c) information sources, which contain sources of information needed by students to complete assignments; (d) process, which contains detailed descriptions of the detailed steps that lead students to complete the assignment; (e) resources, which contain guidelines on how to manage the information obtained; and (f) conclusion, which contains the closure of the work done by students and contains reminders about what students have learned. However, in 2000, Dodge developed a five-stage process that could be used to create WebQuest. The steps are (a) selecting the appropriate topic for WebQuest; (b) choose a design that suits the topic; (c) describe how student evaluations; (d) design the process by finding suitable sources of information; and (e) improve and modify WebQuest. In short, WebQuest components that are approved and used today are introductions, tasks, processes or procedures, resources, and conclusions (Dodge, 2001).

However, the application of WebQuest in the learning process requires the creativity and ability of teachers to use technology. According to Bitner \& Bitner (2002), only a few teachers integrate technology into the curriculum. Teachers do not use technology regularly during their teaching and they also do not integrate technology into the classroom (Bielefeldt, 2001). The obstacles often faced by teachers in applying technology in teaching are the lack of teacher motivation in using technology, lack of training in technology, lack of expert technical staff, and poor administrative support (Habibu, Mamun \& Clement, 2012). Thus, to support the teacher in promoting local wisdom using technology, the researchers will develop learning materials in the form of narrative text through WebQuest with the aim of promoting local culture in Indonesia. 
In addition, some studies have already inserting local culture to English materials. A study from Meliono (2011) shows that introducing local wisdom to students can edify some values such as harmony, nationalism, and morals to build an identity. In line with that, Saputra (2013) also conducted his study about enhancing local wisdom. The result of his study shows that local content in teaching and learning can enhance cultural values in Indonesian society. Furthermore, Fatimah, Sulistyo, and Saddhono (2017) conducted a study about introducing local wisdom values to revitalize behavioral education. The result shows that introducing local wisdom values makes students more nationalistic. Those several studies have similarities with the present study. The previous studies and the present study focus on introducing, promoting, and enhancing local wisdom in teaching and learning. However, the present study uses technology as a tool to promote local wisdom in teaching and learning. It is because the researchers merely found a few studies that integrate technology, especially WebQuest with local culture-based learning. Thus, the present study does the innovation by using WebQuest to promote local wisdom in teaching and learning with the aim of promoting local culture in Indonesia.

\section{METHOD}

This research uses research and development (R\&D) study. Research and development is an industry-based development model whose research results are used to create new products and procedures that will be systematically tested, evaluated and refined until they meet the criteria for quality, effectiveness, or similar standards determined specifically (Borg \& Gall, 2003). The researcher combines and adapts several models from Borg \& Gall (1983), Dick, Carey \& Carey (2001), and Hyland (2003) into four stages such as (1) needs analysis, (2) developing material, (3) expert validation, and (4) revision. The researchers adapt and combine several models to fit the needs, goals, and available resources.

The subject used in this study is tenth-grade students in one vocational high school in Yogyakarta. The subject is chosen because they need more practice in reading to face the national examination Furthermore, another reason is the reading materials used by teachers are more focus on international stories rather than national stories. In addition, this study used qualitative and quantitative data. The qualitative data have been collected from the interview, observation, and suggestion from the expert. The quantitative data were collected from the questionnaire. The first data were interview transcripts. The transcript was analyzed to dig up the information about students' needs in English teaching and learning. The second qualitative data were observation. It was to ensure that the interview and the observation have the same result. The third qualitative data were expert's feedback and suggestion on material designed. The researcher used the data analysis technique proposed by Miles, Huberman \& Saldana (2014) that covering data reduction, data display, and conclusion drawing. Then, the quantitative data were collected from the questionnaire filled out by students. The quantitative data were analyzed by using percentages to find out the highest and the lowest needs of the students.

\section{RESULT AND DISCUSSION}

In this research, the first step carried out to develop the material is need analysis. Need analysis is done to find out information about the needs of students in learning English in vocational schools. The first need analysis is done through interviews with English teachers and tenth-grade students of vocational high school. The results of the interview said that most students in the school did not master reading skills because they lacked vocabulary. It is in line with the statements from Sasmita (2005) and Atikah (2009) that the difficulties in understanding reading text are vocabulary, grammar, spelling, and reading interest. However, students in these schools need reading skills to be used in national examinations. In addition, in reading, narrative text is one of the reasons why students are less motivated to read. Based on reports from teachers, she used international stories more often than national stories. The aim of the teacher was to make the students understood the culture of the language they learned, namely English. However, the teacher forgot that introducing local culture also important. In addition, researchers also conducted interviews with several students who received the highest and lowest scores in English. The conclusion from the results of interviews with students was that they felt difficulties when learning to read, especially on narrative text material. They considered that learning narrative text is very confusing. Besides they did not understand the vocabulary provided, they also did not understand the meaning well. Students also said that the material used by the teacher made them bored because the teacher only provided material in the form of paper while students wanted to get material from various sources including the internet.

After conducting interviews with teachers and students, researchers distributed questionnaires that must be filled out by students. The results of the questionnaire are presented in the table below.

TABLE I. THE RESULTS OF NEEDS ANALYSIS

\begin{tabular}{|c|c|}
\hline \multicolumn{2}{|c|}{ 1. Why do you need to study English? } \\
\hline Higher education & $31,26 \%$ \\
\hline Success for future profession & $59,37 \%$ \\
\hline Pass the national examination & $9,37 \%$ \\
\hline Speak to foreigners & - \\
\hline Others & - \\
\hline \multicolumn{2}{|c|}{ 2. When do you use English? } \\
\hline When studying & $93,75 \%$ \\
\hline When socializing & $6,25 \%$ \\
\hline At home & - \\
\hline Others & - \\
\hline \multicolumn{2}{|c|}{ 3. In the future, I shall be using English for } \\
\hline Higher education & $31,25 \%$ \\
\hline Job/career & $68,75 \%$ \\
\hline Socializing & - \\
\hline
\end{tabular}




\begin{tabular}{|c|c|}
\hline At home & - \\
\hline Others & - \\
\hline \multicolumn{2}{|c|}{$\begin{array}{l}\text { Would you like English to be taken away from } \\
\text { school curriculum because you do not find the } \\
\text { present syllabus and the way of classroom teaching } \\
\text { helpful in fulfilling your needs of English? }\end{array}$} \\
\hline Strongly disagree & - \\
\hline Disagree & - \\
\hline Neutral & $62,50 \%$ \\
\hline Agree & $37,50 \%$ \\
\hline Strongly agree & - \\
\hline \multicolumn{2}{|c|}{$\begin{array}{l}\text { 5. Do you think if a student's level of English is not } \\
\text { good it can have }\end{array}$} \\
\hline A good effect on his academic performance & - \\
\hline A bad effect on his academic performance & $100 \%$ \\
\hline Not effect at all on his performance & - \\
\hline \multicolumn{2}{|c|}{$\begin{array}{l}\text { 6. Do students in your class face difficulty in } \\
\text { understanding the material given by the teacher } \\
\text { because of their poor English? }\end{array}$} \\
\hline Many face a lot of difficulties & $100 \%$ \\
\hline Many face a little difficulty & - \\
\hline They face no difficulty & - \\
\hline \multicolumn{2}{|l|}{ 7. Which skills are emphasized in this class? } \\
\hline Skills & Percentage \\
\hline Reading & $53,13 \%$ \\
\hline Grammar & - \\
\hline Vocabulary & $15,62 \%$ \\
\hline Writing & $6,25 \%$ \\
\hline Speaking & $25,00 \%$ \\
\hline Listening & - \\
\hline \multicolumn{2}{|c|}{$\begin{array}{l}\text { 8. Which of the following areas do you wish to develop } \\
\text { more? }\end{array}$} \\
\hline Skills & Percentage \\
\hline Speaking & $21,87 \%$ \\
\hline Listening & - \\
\hline Reading & $78,13 \%$ \\
\hline Vocabulary & - \\
\hline Writing & - \\
\hline Grammar & - \\
\hline \multicolumn{2}{|l|}{ 9. What kind of English class do you like? } \\
\hline $\begin{array}{l}\text { A class with a lot of activities, pair/group work } \\
\text { and projects }\end{array}$ & $12,50 \%$ \\
\hline $\begin{array}{l}\text { Teaching only by the teacher and no activities by } \\
\text { the students }\end{array}$ & - \\
\hline Teaching with the use of technology & $31,25 \%$ \\
\hline Using online learning in the laboratory & $56,25 \%$ \\
\hline Others & - \\
\hline \multicolumn{2}{|c|}{$\begin{array}{l}\text { 10. Where do you look for information to do } \\
\text { assignments given by the teacher? }\end{array}$} \\
\hline From printed book & $40,63 \%$ \\
\hline From internet/website & $59,37 \%$ \\
\hline From magazine & - \\
\hline Others & - \\
\hline \multicolumn{2}{|c|}{$\begin{array}{l}\text { 11. How do you prefer to do learning activities in the } \\
\text { class? }\end{array}$} \\
\hline Preference for working in pairs or groups & $87,50 \%$ \\
\hline Preference for working alone & $12,50 \%$ \\
\hline \multicolumn{2}{|c|}{ 12. What kind of role do you like your teacher to have? } \\
\hline $\begin{array}{l}\text { Preference for the role of a teacher as a facilitator } \\
\text { and guide }\end{array}$ & $100 \%$ \\
\hline $\begin{array}{l}\text { Preference for the traditional role of the teacher as } \\
\text { someone in control of everything in class }\end{array}$ & - \\
\hline $\begin{array}{l}\text { 13. What do you think about the improve } \\
\text { English knowledge? }\end{array}$ & ment in your \\
\hline English level is not improving & $53,13 \%$ \\
\hline English level is improving & $46,87 \%$ \\
\hline Not sure & - \\
\hline
\end{tabular}

From the results of the student questionnaire above, it can be concluded that the purpose of students learning English is to deal with the fieldwork. All students at the school have difficulty in mastering skills in English, especially reading skills. However, reading skills are needed to face national exams so students choose to develop reading skills even though there are a number of students who want to develop speaking skills. Then, the type of teaching chose by the students is mostly use online learning in the laboratory. Students mostly search for information sources through the internet even though some are looking for information through printed books. In addition, most students prefer to study in groups rather than studying individually. They also want the teacher to act as a facilitator. However, in learning English, almost half of the students feel that their English level is not improving.

After knowing the need analysis from students, the next step is to develop the material. The material developed by researchers is narrative text because students need improvement in reading skills. Researchers also use WebQuest as a learning tool in this study because students want to learn English online so they can access information from various sources. The development of narrative text material through WebQuest is shown in the table below.

TABLE 2.

MATERIAL DESIGN

\begin{tabular}{|c|c|}
\hline Steps & Descriptions \\
\hline Title & Indonesian Folktales \\
\hline Introduction & $\begin{array}{l}\text { Students will study about legend stories such as } \\
\text { Malin Kundang, Bandung Bondowoso, Timun Mas, } \\
\text { Sangkuriang, Danau Toba, etc. }\end{array}$ \\
\hline Task & $\begin{array}{l}\text { - read stories from the places you are visiting } \\
\text { - determine the generic structure of the text } \\
\text { - Summarize the story with your own words } \\
\text { - find the moral value from the story }\end{array}$ \\
\hline Process & $\begin{array}{l}\text {-Step 1: Choose two places. Click on the links to } \\
\text { view the cities/places you can visit and find the } \\
\text { folktales in those places. } \\
\text {-Step 2: Read the stories and find the generic } \\
\text { structure } \\
\text {-Step 3: Summarize the story with your own words } \\
\text {-Step 4: Find the moral value of the stories } \\
\text {-Step 5: Present your work }\end{array}$ \\
\hline Evaluation & $\begin{array}{l}\text {-Reading } \\
\text {-Writing process, Introduction, Spelling and } \\
\text { Punctuation, Solution, Problem, Illustration, and } \\
\text { Characters }\end{array}$ \\
\hline Conclusion & $\begin{array}{l}\text { If you reflect back to the steps you have followed } \\
\text { you will see that you have practiced your reading } \\
\text { and writing perfectly. Now you know more about } \\
\text { some folktales in Indonesia }\end{array}$ \\
\hline
\end{tabular}

The results of the material development above show that students are asked to become independent learners. Students must explore several cities and find the folktales that have been provided. After they choose their preferred folktales, students must read folktales and determine the generic structure of the folktales. After that, students are required to summarize 
folktales that have been read using their own language and find the moral value of the story. By discovering the moral value of folktales, students indirectly learn about local culture in Indonesia. However, before students summarize their chosen folktales, they must consider several points that exist in the evaluation stage so that the results of student assignments can be assessed properly.

Next, after the material is developed, the results of the development are brought to the expert for validation. The quality of WebQuest development is assessed from four aspects, namely contents, language, activities, and graphics. Based on expert comments and suggestions, there are several aspects that must be revised including contents, language, and activities. The content of WebQuest is less diverse so it cannot increase student knowledge. The language used also have some grammatical errors. Then for activities, researchers must develop activities that can be done by students in groups. So, after receiving comments and suggestions from experts, the researchers revised the WebQuest learning material. In content revision, the researchers add some places which have more folktales such as East Java, West Java, Aceh, and so on. The researchers also insert more than two stories in each place. In language revision, the researchers have already improved the grammar until it seems better. Then, in activities revision, the researchers add some activities that involve students in groups such as doing group discussions and making projects. The researcher has done the revision until it is applicable, appropriate and attractive enough.

\section{CONCLUSION AND SUGGESTION}

In conclusion, this study aims to introduce local wisdom through the teaching of narrative text. The learning tool used is WebQuest. The reason for choosing WebQuest as a learning tool is based on student needs. Researchers develop material and content in WebQuest to suit the needs of students in vocational schools. Based on the results of expert validation, the results of the development in this study are appropriate and can be applied in Vocational High School. Then, a suggestion for the next researcher is to be able to develop other material or other types of text with more interesting activities using WebQuest.

\section{ACKNOWLEDGMENT}

We thank to students and English teacher in one of Vocational High School in Yogyakarta who participated in this study. We also thank to some lecturers from Yogyakarta State University who have facilitated this study.

\section{REFERENCES}

Abbitt, J. \& Ophus, J. (2008), What we know about the impacts of WebQuest: a review of research. AACE Journal, 16(4), 441-456.
Ahmadi, M. R. (2018). The use of technology in English language learning: A literature review. International Journal of Research in English Education, $3(2)$.

Alcantara, R. D. (2003). Teaching strategies 1: The teaching of the communication arts: listening, speaking, reading, and writing. Makati City: Katha Publishing Co, Inc.

Anderson, M. \& Anderson, K. (1997). Text types in English 1. South Yarra: Macmillan Education Malaysia.

Anderson, M. \& Anderson. (2003). Text types in English 1-2. Australia: Macmillan Education Australia.

Atikah, I. (2009). Analysis on the student's linguistic problems in reading comprehension: a case study at second grade students of Mts. Baiturrahmah Sukabumi. Thesis Jakarta: State Islamic university.

Bielefeldt, T. (2001). Technology in teacher education. Journal of Computing in Teacher Education, 17(4), 4-15.

Bitner, N. \& Bitner, J. (2002). Integrating technology into the classroom: Eight keys to success. Journal of Technology and Teacher Education, 10, 95100.

Borg, W. R. \& Gall, M. D. (1983). Educational research: an introduction. New York: Longman.

Borg, W. R. \& Gall, M. D. (2003). Educational research: An introduction $\left(7^{\text {th }}\right.$ ed). New York: Pearce Education, Inc.

Brucklacher, B. \& Gimbart, B. (1999). Role-playing software and WesQuest: what's possible with cooperative learning and computers. Computers in the Schools, 15, 37-48.

DfES. (2002). Green Paper 14-19: extending opportunities, raising standards Cm 5342. London: Department for Education and Skills.

Dick, W., Carey, L. \& Carey, J. (2001). The systematic design of instruction (5th ed.). New York: Longman.

Dodge, B. J. (1995). WebQuest: A technique for internet-based learning. Distance educator, 1, 10-13.

Dodge, B. J. (1997). Some thoughts about WebQuest. Available online at: http://webquest.sdsu.edu/about_webquest.html (Accessed 1 September 2019).

Dodge, B. J. (2001). FOCUS: Five rules for writing a great WebQuest. Learning and Leading with Technology, 28(8), 6-9, 58.

Dodge, B. J. (2002). The WebQuest design process. San Diego State University, Educational Technology Department. Available online at: http://webquest.sdsu.edu/designsteps/index.html (Accessed 1 September 2019).

Ezell, D., Klein, C., Hines, R. \& Hall, S. (2003). Using WebQuest with students with disabilities, Center On Disabilities, Proceedings: Technology And persons With Disabilities Conference. Available online at: http//www.csun.edu/cod/conf/2003/proceedings/104.htm (Accessed September 2019). In Press.

Fatimah, F. N., Sulistyo, E. T. \& Saddhono, K. (2017). Local wisdom values in Sayu Wiwit folklore as the revitalization of behavioral education. Journal of Social and Islamic Culture, 25(1), 179-199.

Habibu, T., Mamun, M. \& Clemen, C. (2012). Difficulties faced by teachers in using ICT in teaching-learning at technical and higher educational institutions of Uganda. International Journal of Engineering Research \& Technology, 1.

Harrison, B. (1997). Hardware/software to support distance learning classes. Proceedings of the 1997 Mid-South Instructional Technology Conference. Available online at: http//www.mtsu.edu/itconf/proceed97/harrison (Accessed 1 September 2019). In Press.

Hyland, K. (2003). Genre-based pedagogies: A social response to process. Journal of Second Language Writing, 12, 17-29.

Kurt, I. \& Gok, H. (2015). Impact of technology on the perceptions of culture shock. Mevlana International Journal of Moral and Values Education, 2(2), 21-28.

Littlejohn, A \& Higgison, C. (2003). E-learning series - a guide for teachers, No. 3 (York, Learning and Teaching Support Network Generic Centre). 
Marzano, R. J. (1992). A different kind of class: teaching with dimensions of learning. Alexandria VA: Association for Supervision and Curriculum Development.

Mcknight, Kathrine \& O’Mallley, Kimberly \& Ruzic, Roxanne \& Horsley, Maria \& Franey, John \& Basset, Kathrine. (2016). Teaching in a digital age: how educators use technology to improve student learning. Journal of Research on Technology in Education, 48, 1-18.

Meliono, I. (2011). Understanding the nusantara thought and local wisdom as an aspect of the Indonesian education. International Journal for Historical Studies, 2(2).

Miles, M. B., Huberman, A. M. \& Saldana, J. (2014). Qualitative data analysis, a method sourcebook, ( $3^{\text {rd }}$ ed.). USA: Sage Publications.

Oberholzer, B. (2005). The relationship between reading difficulties and academic performance. Thesis. University of Zululand's Library Catalogue. Available online at: http://uzspace.uzulu.ac.za/handle/10530/398 (Accessed 13 September 2019).

Prajogo, D. I., \& Ahmed, P. K. (2006). Relationships between innovation stimulus, innovation capacity, and innovation performance. $R \& D$ Management, 36(5), 499-515.
Puspita, A. (2017). Student's difficulties in comprehending English reading text at second grade students of SMAN 2 Metro. S1 Thesis. English Education Study Program. University of Lampung.

Saputra, G. A. S. (2013). Enhancing local wisdom through local content of elementary school in Java, Indonesia. Proceeding of the Global Summit on Education. In Press.

Sasmita, E. (2012). Identifying students' abilities in understanding English reading texts: a case study at the second year students of Smkn 1 Gangga in academic Year 2012/2013. Available online at:http://fkipunram.ac.id/ejurnal/index.php/inggris/article/view/235 (Accessed 15 September 2019)

Seitkazy, P. B., Toluebekova, R. K., Amanova, A. K., Tashetov, A. A., Iskakova, G., \& Demissenova, S. S. (2016). A Web-Quest as a teaching and learning tool. IEJME-Mathematics Education, 11(10), 3537-3549.

Zheng, R., Perez, J., Williamson, J., \& Flygare, J. (2007). WebQuests as perceived by teachers: implications for online teaching and learning. Journal of Computer Assisted Learning, 24, 295-304. 